\title{
ZAKAT PRODUKTIF SEBAGAI TITIK TOLAK KEBANGKITAN PERADABAN ISLAM
}

\author{
Samheri \\ Dosen STIU (Sekolah Tinggi IlmuUsuluddin) \\ Al Mujtama' Pamekasan \\ Email: samheri.msh@gmail.com
}

\begin{abstract}
Absrak:
Zakat merupakan salah satu rukun Islam yang berkaitan langsung dengan masalah kekayaan dan kesejahteraan umat Islam. Salah satu tujuan utama zakat adalah pemerataan kekayaan dan kesejahteraan sehingga dapat mengurangi jurang pemisah antara kaum aghniyā' (kaya) dan kaum mustad'afīn (lemah). Oleh sebab itu, pendistribusian zakat selalu dipreoritaskan pada kaum yang lebih lemah.
\end{abstract}

Kata kunci: Zakat, Muzakki, Mustahiq, Kebangkitan, peradaban, Islam Abstract:

Zakat is one of the pillars or one of principles of islam, as we know Zakat is directly related to wealth or welfare of Muslim. The main goal of Zakat is equalization in economic issue because of that Zakat is designed to reduce a gap between a rich man (Aghniyā') and poor man (Mustad'afin). So, the distribution of Zakat is always being focus in its implementation and of course prioritized to the poor man.

Keywords: Zakat, is equalization in economic, the distribution

\section{Prolog}

Zakat merupakan salah satu rukun Islam yang wajib diamalkan oleh setiap umat Islam di seluruh belahan bumi dengan tujuan, antara lain: pemerataan kekayaan dan kesejahteraan, sehingga dapat mengurangi jurang pemisah antara kaum aghniyā' (kaya) dan kaum mustạ̣'afīn (lemah). Zakat dapat dijadikan tolok ukur keimanan seorang muzakki (orang yang membayar zakat), sebab ia merupakan manifestasi daripada rasa sabar dan syukur yang bersumber dari keimanan, keislaman, keihsanannya dan bahkan rasa prikemanusiaan, seperti rasa simpati dan empati yang dimiliki oleh anak adam yang jiwanya tercerahkan. Oleh sebab itu, para muzakki berkeyakinan bahwa zakat dapat membersihkan harta, menenangkan jiwa, mencegah balā' dan musibah yang akan menimpa diri mereka. Di samping itu, zakat juga dapat menumbuhkan rasa persaudaraan (ukhwah islämiyyah) 
yang dapat menghilangkan rasa dendam, iri hati, dengki dan penyakit hati lainnya yang kemungkinan ada pada diri kaum yang lemah dan serba kekurangan.

Pemerataan kakayaan dan kesejahteraan di kalangan umat Islam dapat menumbuhkan persatuan dan kesatuan di antara umat Islam dalam berbagai aspek kehidupannya, seperti dalam bidang mu'āmalah, iqtiṣādiyyah, tarbiyah, ijtimā'iyyah, istisnā'iyyah dan lain sebagainya. Salah satu tujuan utama pensyariatan zakat, wakaf, hibah, sedekah, adalah agar tidak terjadi penumpukan harta di kalangan orang-orang kaya di antara umat manusia sebagaimana firman Allah dalam al-Qur'an al-Karim yang berbunyi: ${ }^{1}$
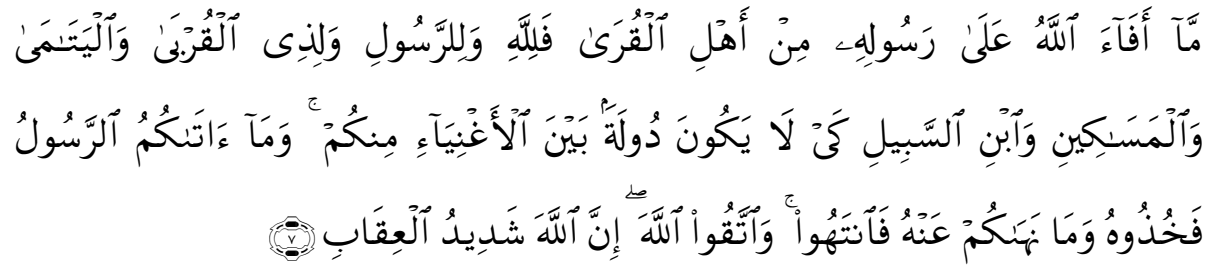

"Apa saja harta rampasan perang (fai') yang diberikan Allah kepada RasulNya (dari harta benda) yang berasal dari penduduk kota-kota, maka adalah untuk Allah, untuk rasul, kaum kerabat, anak-anak yatim, orang-orang miskin dan orang-orang yang dalam perjalanan, supaya harta itu jangan beredar di antara orang-orang kaya saja di antara kamu. apa yang diberikan Rasul kepadamu, maka terimalah; dan apa yang dilarangnya bagimu, maka tinggalkanlah; dan bertakwalah kepada Allah. Sesungguhnya Allah amat keras hukumannya" (QS. al-Hashr [59]: 7).

Pendistribusian harta zakat ini telah dijelaskan dan dirinci di dalam al-Qur'an al-Karim Surah al-Taubah ayat 60 yang menyatakan bahwa sesunggunya zakat itu hanyalah untuk orang orang fakir, miskin, amil, muallaf, hamba sahaya, orang yang berhutang, sabīlillāh dan ibnu sabīl (musafir). Namun demikian, dalam sejarahnya, para mujtahid berbeda pendapat dalam mendistribusikan harta zakat, disebabkan karena perbedaan situasi dan kondisi yang menentukan demikian itu, seperti keputusan Umar bin Khattāa yang tidak menjadikan muallaf sebagai daftar penerima zakat dengan alasan, bahwa saat itu, para muallaf dianggap tidak lagi memerlukan bantuan dari pihak lain, karena mereka tergolong orang-orang yang sukses dan berjaya. Begitu pula undang-undang hukum Islam di beberapa negeri di Malaysia, ada yang tidak memasukkan riqāb (hamba sahaya) dan ghārimīn (orang yang berhutang) sebagai calon penerima zakat, dengan alasan hampir

\footnotetext{
${ }^{1}$ QS. al-Hashr, ayat 7.
} 
semua orang yang memiliki perusahaan atau syarikat juga memiliki tanggungan hutang piutang.

\section{Makna Zakat, Muzakkỉ dan Mustahiq}

Makna zakat secara lughatan, kata zakat berasal dari bahasa Arab yaitu kata زئكي - زكوة jada pula kata yang sama dengan kalimat ini yaitu - زكى (zakkā-yuzakkí-zakātan) yang berarti mengembangkan, menumbuhkan, menyucikan, membersihkan membayar zakat dan lain-lain ${ }^{2}$. Menurut T.M. Hasbi al-Shiddieqy makna zakat menurut bahasa berasal dari kata (namā') yang berarti Kesuburan, طركة (taharah) berarti kesucian dan بركا (barakah) yang berarti keberkatan, atau dikatakan تزكية والتطهير (tazkiyah dan tathir) mensucikan, bertambahnya kebaikan. ${ }^{3}$

Dari beberapa pengertian secara bahasa di atas, dapat diketahui bahwa zakat secara bahasa memiliki makna yang beraneka ragam, bisa juga bermakna menyucikan atau membersihkan atau bermakna lain seperti tumbuh dan berkembang sebagaimana firman Allah yang berbunyi “محق الله الربا " yang berarti “Allah akan menghancurkan riba dan menumbuhkembangkan sedekah".

Sedangkan zakat secara terminologi (hukum shara'), ulama fikih berbeda pendapat diantaranya adalah imam al-Mawardi dalam kitabnya alHâwì al-Kabïr mendefinisikan, zakat adalah sebutan bagi pengambilan harta tertentu, dari harta tertentu, menurut zifat-sifat tertentu untuk diberikan kepada orang-orang tertentu". Pengarang kitab Rauḍah al-Tâalibìn menyebutkan bahwa zakat merupakan salah satu dari rukun Islam, barang siapa yang menentangnya (mengingkarinya) maka ia termasuk orang yang kafir, dan barang siapa yang meyakini kewajibannya, tapi enggan membayarnya, maka hartanya dapat diambil secara paksa oleh penguasa, bahkan șạhibul māl-nya boleh diperangi jika ia masih membangkang. ${ }^{5}$

\footnotetext{
2 Atabik Ali dan Ahmad Zuhdi Muhdlor (1999), Kamus al-‘Asri: Arab-Indonesia (Yogyakarta: Yayasan Ali Ma'sum, Pondok Pesantren Krapyak), 1017.

${ }^{3}$ Shaikh Shamsuddin Muhammad ibnu al-Khatīb al-Sharbini (1998), Mughnì al-Muhtạj ilā ma'rifati ma'ānī al-alfāz al-Minhāj, Cet.1, Vol. 1, (Bairut: Dār al-Ma'rifah),547; bandingkan juga dengan tulisan T.M. Hasbi al-Shiddieqy (2006), Pedoman Zakat, cet. Kesebelas, edisi kedua (Semarang: PT. Pustaka Rizki Putra), 3.

${ }^{4}$ Abū al-Hasan Ali bin Muhammad bin Habỉb al-Mawardi al-Basrì (1994), al-Hāwī al-Kabīr fì fiqh madhāhib al-Imām al-Shāfi ī Raḍiya Allāhu 'anhu, Cet. 2, Vol. 3, (Bairut, Lubnān: Dār al-Kutub al-Ilmiah), 71.

${ }^{5}$ Abū Zakariyā Yahyā bin Sharaf al-Nawawì al-Dimashqī (2003), Rauḍạ̣ al-Tālibīn, Juz 2 (Dār Alām al-Kutub), 3.
} 
Makna zakat dari kacamata perundang-undangan Islam di Indonesia, Undang-Undang Republik Indonesia, Nomor 38 Tahun 1999 tentang pengelolaan zakat, yang diamandemen dengan Undang-undang nomor 23 tahun $2011^{6}$ pasal 1 , ayat 3 tentang zakat, menjelaskan bahwa zakat adalah harta yang wajib dikeluarkan oleh seorang muslim atau badan usaha untuk diberikan kepada yang berhak menerimanya sesuai dengan shariat Islam"

Berdasarkan paparan di atas, maka dapat dipahami bahwa zakat merupakan kewajiban bagi orang-orang tertentu untuk mengeluarkan sebagian hartanya yang tertentu dan dibagikan kepada orang-orang tertentu sebagaimana yang telah ditegaskan dalam Firman Allah surah al-Taubah ayat $60 \mathrm{itu}$.

Adapun yang dimaksud dengan kewajiban bagi orang-orang tertentu untuk mengeluarkan sebagian hartanya adalah para muzakki (orang yang berkewajiban mengeluarkan zakat). Jumhur ulama menyatakan bahwa orang yang disepakati wajib mengeluarkan zakat adalah merdeka, telah sampai umur, berakal dan niṣāb yang sempurna. Sedangkan harta yang wajib dikeluarkan zakatnya yang disepakati mayoritas ulama adalah emas, perak dan binatang ternak dan penuh setahun dimiliki oleh muzakki. ${ }^{7}$ Hal itu, sudah banyak dijelaskan ulama fikih pada umumnya.

Setelah membahas makna zakat dan muzakki, selanjutnya perlu dibahas mengenai mustahiq al-zakāh (orang-orang yang berhak menerima zakat). Di antara dalil yang dijadikan dasar hukum bagi pendistribusian zakat adalah Firman Allah Swt. dalam QS. al-Taubah, ayat 60:

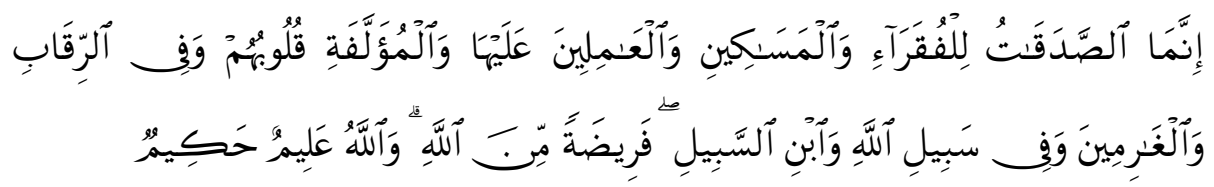

"Sesungguhnya zakat-zakat itu, hanyalah untuk orang-orang fakir, orangorang miskin, pengurus-pengurus zakat, para muallaf yang dibujuk hatinya, untuk (memerdekakan) budak, orang-orang yang berhutang, untuk jalan Allah dan untuk mereka yang sedang dalam perjalanan, sebagai suatu

\footnotetext{
${ }^{6}$ Adapun yang menjadi pertimbangan Pemerintah dalam amandemen Undang undang ini adalah bahwa Undang-Undang Nomor 38 Tahun 1999 tentang Pengelolaan Zakat sudah tidak sesuai dengan perkembangan kebutuhan hukum dalam masyarakat sehingga perlu diganti;

${ }^{6}$ T.M. Hasbi al-Shiddieqy (2006), Pedoman Zakat, cet. Kesebelas, edisi kedua (Semarang: PT. Pustaka Rizki Putra), 19.
} 
ketetapan yang diwajibkan Allah, dan Allah Maha Mengetahui lagi Maha Bijaksana. $^{8}$

Dari delapan aṣnāf di atas, maka yang masih dianggap berhak menerima zakat hanyalah enam saja, yaitu fakir, miskin, amil, ghārim, sabìililāh, dan ibnu sabīl, sebab realitanya, hari ini sudah tidak ada lagi sistem perbudakan atau hamba sahaya di belahan bumi manapun, karena dianggap tidak sesuai dengan pri-kemanusiaan dan pri-keadilan. Demikian juga muallaf, dimana sejak masa ke-khalifahan Abu Bakar dan Umar bin Khottāb, para muallaf tidak lagi diberikan bagian harta zakat dengan alasan fatwa Umar bin Khatțāb yang menyatakan:

"Dahulu Rasulullah menganggap kalian sebagai muallaf, ketika Islam saat itu masih kecil dan pemeluknya masih sedikit, namun karena sekarang Allah telah menjadikan Islam semakin besar dan berjaya, maka pergilah kalian bekerja sebagaimana kaum muslimin bekerja. Kebenaran adalah berasal dari Tuhan kalian. Barang siapa yang mau beriman, maka berimanlah, dan barang siapa yang mau kufur, maka kufurlah"."

Berdasarkan cuplikan fatwa Umar bin Khațāa di atas, dapat diambil suatu pemahaman bahwa distribusi zakat diutamakan bagi kaum yang lemah yang masih memerlukan bantuan dari pihak-pihak yang berkemampuan. Oleh karena itu, perlu ada preoritas dalam mendistribusikan zakat, supaya tujuan pensyariatan zakat dapat tercapai dengan baik, sebagaimana yang terjadi pada masa pemerintahan Umar bin 'Abdul 'Aziziz, yang konon para pengelola zakat kesulitan mencari orang yang mau menerima zakat.

Ada hal yang menarik penulis untuk membicarakan masalah yang berkaitan dengan mustahiq al-zakāh, selain dua bahasan di atas, yaitu makna sabīililāh. Secara bahasa, sabīlillāh ini berarti jalan Allah. Sedang menurut hukum shara', sabīillāh dalam pembahasan thamāniyat al-aṣnāf (para penerima zakat yang delapan) adalah orang-orang yang berperang di jalan Allah, sebagaimana telah dinyataka secara jelas dan tegas dalam hasil Keputusan Muktamar Nahdlatul Ulama ke-1, di Surabaya, pada tanggal 13 Rābi‘ al-Thāni 1345/21 Oktober 1926 M. bahkan muktamirīn (ulama yang tergabung dalam bahthul masāil dalam muktamar) menunjukkan ketidaksetujuannya terhadap pendapat yang dikemukakan oleh Imam alQaffāl dengan mengatakan bahwa pendapat Imam Qaffāl itu da' 'if (lemah). ${ }^{10}$

\footnotetext{
${ }^{8}$ QS. al-Taubah [9]: 60.

9 Dr. Muhammad Baltaji (2007), Ijtihad Umar bin Khattab Dalam Penetapan Syariat Islam (Selangor: Berlian Publication SDN. BHD), h. 193.

${ }^{10}$ Imam Ghazali Said dan A. Ma'ruf Asrori (2005), Ahkām al-Fuqahā': Solusi Problematika Aktual Hukum Islam, Keputusan Muktamar, Munas dan Kombes Nahdlatul Ulama 1926-
} 
Senada dengan keputusan Muktamar NU ini, apa yang dikemukakan oleh alSayid Sābiq dalam kitabnya fiqh al-Sunnah, bahwa jumhur ulama menafsirkan sabīlillāh adalah perang, dengan tujuan agar distribusi zakat ini dapat diberikan kepada pasukan perang yang tidak menerima honor atau gaji dari pemerintah (relawan perang). ${ }^{11}$

Adapun pendapat Imām Qaffāl yang dikutip oleh pengarang tafsir alMunir, juz 1 adalah sebagai berikut:

$$
\begin{aligned}
& \text { ونقل القفال عن بعض الفقهاء أفم أجازوا صرف الصدقات إلى جميع وجوه الخير من تكفين الموتى وبناء الحصون }
\end{aligned}
$$

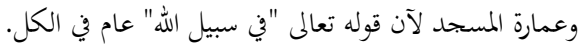

"Imam al-Qaffăl mengutip dari sebagian ulama fikih bahwasanya mereka memperbolehkan penggunaan hasil sedekah atau zakat bagi semua jalar kebaikan, seperti pengkafanan janazah, pembangunan benteng, dan pembangunan masjid, karena firman Allah "Sabilillạh" bersifat umum dan mencakup keseluruhannya."12

Demikian juga nasib ibnu sabīl di era kamajuan teknologi dewasa ini. Menurut Hasbi al-Shiddieqy, ketika beliau menafsirkan kata ibnu sabīl dalam surat al-Hashr, beliau mengatakan Ibnu sabil yang berhak menerima bantuan adalah orang yang kehabisan bekal di tengah perjalanan, dan tidak mungkin meminta bantuan bekal dari kampungnya dengan mudah. Menurutnya, pada era kemajuan komunikasi dan transportasi seperti sekarang, dimana antara satu daerah dengan daerah lainnya sudah berjalan lancar dan mudah, maka dapat dipastikan bahwa orang yang kehabisan bekal dalam perjalan dapat meminta bekal pada keluarganya di kampung halamannya. Oleh karena itu, pada dewasa ini boleh dikatakan tidak banyak lagi ibnu sabīl (yang berhak menerima sedekah ataupun zakat). ${ }^{13}$

Berdasarkan penjelasan di atas, dan melihat kenyataan hari ini, maka dapat diambil sebuah pemahamaan bahwa dari delapan așnăf yang diperinci dalam Surat al-Taubah ayat 60 itu, hanya khamsat al-aṣnăf (lima golongan) yang berhak dan layak untuk dijadikan prioritas dalam distribusi harta zakat ini. Distribusi harta zakat tidak boleh dibagikan ke daerah di luar batas

1999. Cet.2. (Surabaya: LTN-NU JATIM-Diantama), h. 7. Selanjutnya, ditulis Ahkām alFuqahā.

11 Al-Sayyid Sạbiq (ttb), Fiqh al-Sunnah, Edisi Khusus, Vol, (Kairo: al-Fath lil a'lạm al'Arabī), 280.

12 Ibid. 7.

13 Menurut T.M. Hasbi ash-Shiddiqieqy (2011), Tafsīr al-Qur'ān al-Majīd al-Nür, Vol. 4, (Jakarta: Cakrawala Publishing), 305. 
balad. $^{14}$ Dengan demikian, maka khusus daerah Madura ini tidak perlu dianggarkan distribusi zakat bagi sabīlillāh, mengingat Madura pada khususnya dan Indonesia pada umumnya sedang aman dan tidak dalam masa peperangan, sehingga ke depan harta zakat lebih difokuskan pada pemberdayaan dan pemandirian fakir-miskin dan kaum lemah lainnya dan dikelola secara produktif dan kreatif.

\section{Tujuan dan Hikmah Zakat}

Para fuqaha' sudah banyak membahahas tentang materi ini, namun penulis hendak mengungkapkan fakta yang jarang sekali diungkapkan oleh penulis lain, sebagaimana berikut:

1. Zakat bertujuan agar tidak terjadi penumpukan harta di antara orang-orang kaya di antara umat Islam, hal itu sesuai dengan firman Allah yang berbunyi ${ }^{15}$

2. Menolong orang-orang yang lemah dan susah, agar ia dapat menunaikan kewajibannya terhadap Allah dan terhadap masyarakat yang memerlukannya. ${ }^{16}$

3. Membersihkan diri dari sifat kikir dan akhlak yang tercela, serta mendidik diri agar bersifat mulia dan pemurah dengan membiasakan diri menunaikan amanah kepada orang-orang yang berhak dan memerlukannya. ${ }^{17}$

4. Sebagai ucapan syukur dan terima kasih atas nikmat kekayaan yang diberikan kepadanya, tidak diragukan lagi, bahwa yang diperlihatkan oleh orang yang diberi kepada orang yang memberi adalah suatu kewajiban yang terpenting menurut ahli etika dan kesopanan. $^{18}$

5. Meminimalisir kejahatan yang mungkin akan ditimbulkan orangorang yang terdesak untuk memenuhi kebutuhan diri dan keluarganya. Dalam kehidupan nyata, betapa banyak orang baikbaik menjadi kasar, jahad, dan kejam kemudian merusak dan

\footnotetext{
${ }^{14}$ Ulama berbeda pendapat dalam memberikan batas balad ini, ada yang menyamakan dengan batas kampung salat Jumat, ada juga yang membatasi dengan jarak diperbolehkannya salat qașar at au jama' dalam perjalanan.

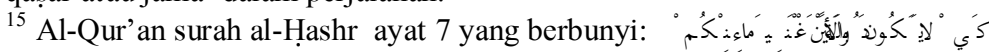

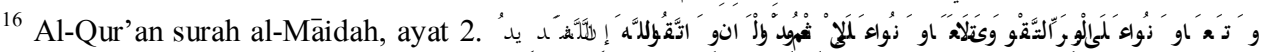
الْعَعَاب

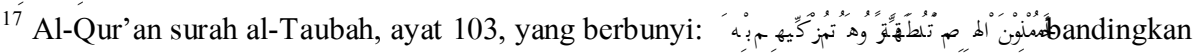

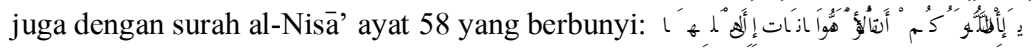

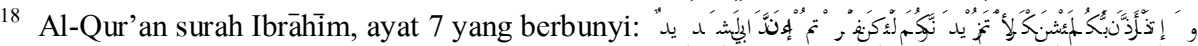


menyusahkan lingkungan sekitarnya dengan alasan memperjuangkan dan mempertahankan nasib diri dan hidup keluarganya. ${ }^{19}$

6. Memupuk rasa kasih sayang di antara muzakki dan mustahiq, yang dapat mempererat hubungan tali silaturrahmi antara si kaya dan si miskin, sehingga terjadi komunikasi yang lebih inten dan gotong royong yang akan selalu terbina di antara umat Islam. ${ }^{20}$

7. Meringankan beban Anggaran Pendapatan Belanja Negara atau Daerah (APBN/ APBD), sebab potensi zakat, jika dikelola secara baik dan benar, didistribusikan sesuai target, sasaran dan prioritasnya, maka kumpulan harta zakat dalam suatu daerah bisa menjamin pendidikan atau kehidupan anak yatim dan fakir-miskin yang semestinya ditanggung oleh pemerintah melalui APBN/APBD. Hal itu, sesuai dengan Undang-undang Dasar (UUD) 1945, Republik Indonesia, pasal 34 ayat 1, yang berbunyi, "Fakir miskin dan anakanak yang terlantar dipelihara oleh negara".

Berdasarkan paparan di atas, dapat diambil beberapa pemahaman bahwa zakat bertujuan untuk pemerataan di antara umat Islam, mengentaskan kemiskinan, meminimalisir kebodohan dengan cara harta zakat dijadikan jaminan untuk membiayai generasi muslim berprestasi tetapi tidak cukup biaya untuk melanjutkan ke jenjang pendidikan yang lebih tinggi. Setelah kebutuhan hidup dan pendidikan umat Islam terpenuhi, maka selanjutnya generasi muslim menjadi generasi yang cerdik dan pandai, sehingga mereka dapat membentuk sebuah komunitas yang kuat dan tangguh dan tidak lagi bergantung kepada bantuan orang lain. Bahkan diharapkan dapat membantu orang lain yang masih memerlukan bantuan dan uluran tangnnya, seperti adanya bencana alam, gizi buruk, dan gejala sosial lainnya, seperti contoh yang pernah dilakukan Majlis Ugama Islam Singapura (MUIS), dimana harta wakaf dan zakat pernah dibelanjakan untuk membeli obat-obatan di rumah sakit-rumah sakit yang dipergunakan untuk orang-orang miskin yang tidak memungkinkan membiayai pengobatannya di rumah sakit di Singapura. ${ }^{21}$

\footnotetext{
${ }^{19}$ Sulaiman Rasjid (2004), al-Fiqh al-Islami, (Bandung: Sinar Baru Algensindo, cet. 37, t.t), 217.

${ }^{20}$ Al-Qur'an surah al-Hujurāt, ayat 10, yang berbunyi 'تر

${ }^{21}$ Hasil wawancara dengan Dr. Syamsiah, salah satu pengurus di MUIS Singapura, bidang Wakaf dan zakat yang berkantor di Islamic Hub Singapura.
} 


\section{Strategi Pengumpulan Zakat}

T.M. Hasbi al-Shiddiqy ${ }^{22}$ bersetuju untuk mewajibakan penguasa untuk memungut atau mengumpulkan zakat dari orang-orang wajib zakat dengan berdasarkan surah al-Taubah ayat 103 yang berbunyi:

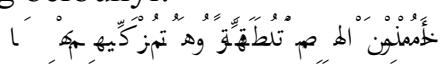

Ambillah sedekah (zakat) dari harta-harta mereka supaya dapat mensucikan dan membersihkan diri mereka.

Sebagian ulama tafsir menafsirkan ayat ini sebagai perintah wajib bagi para penguasa untuk memungut zakat dari mereka yang wajib mengeluarkan zakat itu sendiri. Mereka memperkuat pendapatnya dengan hadis Nabi yang diriwayatkan oleh imam al-Bukhārỉ yang berbunyi:

$$
\text { تؤخذ من أغنيائهم فترد على فقرائهم }
$$

Yang bermaksud "diambil dari (zakat) dari orang-orang kaya mereka, dan didistribusikan kepada orang-orang fakir di antara mereka."

Berdasarkan pemahaman ayat dan hadis di atas, mayoritas ulama berpendapat bahwa penguasa boleh memerangi orang-orang yang enggan membayar zakat, karena zakat merupakan sebagian daripada rukun Islam, bahkan ulama membolehkan mengambil hartanya secara paksa jika mereka tetap tidak mau membayarkan zakatnya itu, sebagaimana yang pernah dilakukan oleh khalifah yang pertama, yaitu Abū Bakar al-Șiddiq ra. ${ }^{23}$

Bahkan ulama membolehkan menyerahkan zakat kepada kepala Negara yang tidak adil dengan berdasarkan kepada hadis Nabi yang diriwayatkan oleh Imam Ahmad bin Hambal dari Anas bin Mālik r.a., yang bermaksud:

"Sesungguhnya seorang lelaki bertanya kepada Rasulullah, bolehkan saya menyerahkan zakat kepada utusanmu, adakah saya telah terlepas dari kewajiban membayar zakat kepada Allah dan rasulnya? Nabi menjawab, ya. Jika kamu sudah membayar kepada salah satu utusan (petugas lapangan), maka kamu sudah bebas dari tuntutan Allah dan rasul-Nya, dan kamu memperoleh pahalanya, sedang dosanya akan diperoleh oleh orang-orang yang menukarkannya". ${ }^{24}$

Dalam kontek ke-Indonesiaan, maka yang dimaksud dengan Penguasa dalam bab pengelolaan zakat ini adalah Badan Amil Zakat Nasional (BAZNAS) yaitu lembaga yang melakukan pengelolaan zakat secara

\footnotetext{
${ }^{22}$ T.M. Hasbi al-Shiddieqy (2006), Pedoman Zakat, edisi II (Semarang: PT. Pustaka Rizki Putra, cet. Ke 11, t.t.), 56.

${ }^{23}$ Shaikh Shamsuddin Muhammad ibn al-Khātib al-Sharbīnì (1998), Mughnī al-Muhtạj ilā Ma'rifat Ma’ānì al-Alfāz al-Minhāj, Vol. 1, (Bairut: Dār al-Ma'rifah, Cet.ke-1,), h. 547;

${ }^{24}$ T.M. Hasbi Ash-Shiddieqy, Pedoman Zakat, edisi II (Semarang: PT. Pustaka Rizki Putra, Cet. Ke-11, 2006)), 58.
} 
nasional; dan atau Lembaga Amil Zakat (LAS) yaitu lembaga yang dibentuk masyarakat yang memiliki tugas membantu pengumpulan, pendistribusian, dan pendayagunaan zakat. ${ }^{25}$

Selanjutnya, pengelola zakat dikenal dengan sebutan 'àmil zakat. Sedang hak 'àmil adalah bagian tertentu dari zakat yang dapat dimanfaatkan untuk biaya operasional dalam pengelolaan zakat sesuai dengan syariat Islam. $^{26}$

Pengelolaan zakat bertujuan untuk meningkatkan efektivitas dan efisiensi pelayanan dalam pengelolaan zakat; dan juga bertujuan untuk meningkatkan manfaat zakat untuk mewujudkan kesejahteraan masyarakat dan penanggulangan kemiskinan. ${ }^{27}$

Dalam melaksanakan tugas sebagaimana dimaksud dalam Pasal 6, BAZNAS menyelenggarakan fungsinya sebagai berikut:

zakat;

a. perencanaan pengumpulan, pendistribusian, dan pendaya-gunaan zakat;

b. pelaksanaan pengumpulan, pendistribusian, dan pendaya- gunaan zakat;

c. pengendalian pengumpulan, pendistribusian, dan pendaya-gunaan zakat.

d. pelaporan dan pertanggungjawaban pelaksanaan penge-lolaan

Kedua lembaga pengelala zakat di atas, baik BAZNAS maupun LAZ dibentuk dan diijinkan oleh pemerintah dan disahkan berdasarkan Undangundang dan peraturan perundang-undangan yang berlaku di Indonesia. Sebagimana bunyi undang-undang zakat di bawah ini:

Pasal 10

(1) Anggota BAZNAS diangkat dan diberhentikan oleh Presiden atas usul Menteri (yang dimaksud dengan Menteri di sini adalah Menteri Agama).

Pasal 15 ayat 2 dan 3.

\footnotetext{
${ }^{25}$ Peraturan Pemerintah Republik Indonesia. Nomor 14 tahun 2014 Tentang Pelaksanaan Undang-undang Nomor 23 Tahun 2011 Tentang pengelolaan zakat, pasal 1 ayat 2-3; bandingkan juga dengan Undang-undang Republik Indonesia Nomor 23 Tahun 2011 Tentang Pengelolaan zakat, pasal 1 ayat 7-8.

${ }^{26}$ Peraturan Pemerintah Republik Indonesia. Nomor 14 tahun 2014 Tentang Pelaksanaan Undang-undang Nomor 23 Tahun 2011 Tentang pengelolaan zakat, pasal 2 ayat 5; bandingkan juga dengan Undang-undang Republik Indonesia Nomor 23 Tahun 2011 Tentang Pengelolaan zakat. Pasal 1 ayat 11 .

27 Undang-undang Republik Indonesia Nomor 23 Tahun 2011 Tentang Pengelolaan zakat. Pasal 3 poin a dan $b$.
} 
(2) BAZNAS provinsi dibentuk oleh menteri atas usul gubernur setelah mendapat pertimbangan BAZNAS.

(3) BAZNAS kabupaten/kota dibentuk oleh menteri atau pejabat yang ditunjuk atas usul bupati/walikota setelah mendapat Pasal 18 ayat 1. pertimbangan BAZNAS.

Pembentukan LAZ wajib mendapat izin menteri atau pejabat yang ditunjuk oleh menteri (yang dimaksud dengan menteri di sini adalah Menteri Agama).

Dalam fenomena masyarakat Islam di Indonesia terlihat masih kuatnya kecenderungan mereka dalam mengeluarkan zakat secara sendirisendiri (tidak melalui badan atau lembaga amil zakat). Akibatnya justru menimbulkan sikap fatalistik (penyerahan diri secara total dan lemah dalam beruasaha) di kalangan ç $^{\prime}$ 'afä, karena rasa tamaknya yang besar atas pembagian zakat yang secara rutin akan diterima. Di sini, zakat kemudian menimbulkan kerawanan mental tersendiri, yang dapat berakibat mematikan kreatifitas dan etos kerja bagi penerima zakat. Hal ini menyudutkan mereka di tengah-tengah kemajuan rekayasa ekonomi dan teknologi dewasa ini. ${ }^{28}$

Berdasarkan paparan data di atas, dapat dikatakan bahwa zakat yang dikelola dan atau sepengetahuan pemerintah dianggap lebih transparan dan lebih mendatang manfaat bagi para penerima zakat. Hal itu, disebabkan karena badan atau lembaga pengelola zakat tersebut bertanggung jawab untuk mengentaskan kemiskinan dengan berbagai cara dan usaha yang paling memungkinkan. Selain daripada, LAZ/BAZ sama-sama memiliki program dan perencanaan serta manajemen dan pengelolaan zakat yang lebih terarah dan bisa dimintai pertanggungjawabannya setiap saat, ketika diperlukan.

Namun demikian, pengurus BAZNAS maupun LAZ sama-sama terbatas hanya di perkotaan dan belum mampu menjankau pedesaan dan perkampungan yang masih jauh dari titik kemajuan. Oleh sebab itu, pengurus BAZNAS maupun LAZ ke depan diharapkan bisa bekerjasama dengan para kiai dan atau tokoh masyarakat setempat yang memiliki simpati bahkan empati dari masyarakatnya masing-masing.

${ }^{28}$ Khusnul Huda (2012), Fikih Pengelolaan Zakat Produktif Sebagai Upaya Pengembangan Sumber Daya Mustahik (Studi Kasus Di Badan Pelaksana Urusan Zakat Muhammadiyah (BAPELURZAM) Pimpinan Cabang Muhammadiyah Weleri Kendal, sinopsis Tesis (Semarang: Program Magister Institut Agama Islam Negeri (IAIN) Walisongo Semarang),13. 
Masyakat Madura kebanyakan berpegang teguh pada falsafah nenek moyangnya yang dikenal dengan sebutan "Buppak babuk guru rato"29, bahwasanya masyarakat Madura dalam memberikan penghormatannya mengikuti urutan falsafahnya itu, yaitu penghormatan pertama, diperuntukkan bagi ayah dan ibunya; kedua, diberikan kepada guru atau kiainya, sedangkan yang ketiga diberikan kepada para penguasa. Oleh karena itu, tidak mengherankan jika mereka lebih menghormati kiai daripada bupati atau gubernur bahkan presiden sekalipun. ${ }^{30}$

Dengan demikian, maka untuk mewujudkan pengelolaan zakat produktif dan kreatif ini, diperlukan kerjasama dengan para kiai, guru ngaji, ustadz dan lain-lian yang memiliki simpati dan empati dari masyarakat yang mengagkat diri mereka itu sebagai tokoh kharismatik di daerahnya, sehingga semua program akan berjalan sebagaimana mestinya, sebab masyarakat Madura tidak mungkin dapat membantah apa yang diinstruksikan para ulama atau kiai yang dianutinya.

Setelah kiai menyepakati pengelolaan zakat produktif ini, maka kemudian dianggap perlu juga bekerjasama dengan kepala desa dan perangkat desa lainnya, supaya mereka bergerak dengan menggunakan pendekatan struktural jabatannya, sementara para kiai, guru ngaji dan para ustadz akan bergerak secara natural dan tradisional di tingkatan grase-root. Sedangkan kelompok terakhir yang perlu diajak kerjasama juga untuk melakukan pengelolaan dan pengembangan harta zakat produktif ini adalah pemuda dan abangan. ${ }^{31}$ Mereka ini merupakan aset kekayaan daerah yang harus mendapatkan perhatian dan posisi yang strategis, sehingga aktivitas dan gerakan mereka lebih terarah kepada hal-hal yang positif dan produktif. $^{32}$ Seperti mengumpulkan zakat dan mendistribusikan serta

${ }^{29}$ Lembaga Pengkajian dan Penerapan Syariat Islam (LP2SI) di Pamekasan menafsirkan filosofi masyarakat Madura ini dengan mewujudkan sesuatu masyarakat Madura dimulai dari individu dan keluarganya yang Islami, pendidikan yang Islami, aparatur Negara yang Islami dengan prinsip “ Mekkas Jatnah Paksa Jenneng Dibi" " yang bermaksud bahwa dengan kemampuan sendiri dan didukung oleh masyarakat kabupaten Pamekasan menjalankan pemerintahannya. Lebih lanjut, silahkan baca buku terbitan LP2SI (2010), mengenal Gerbang Salam (Gerakan Pembangunan Masyarakat Islami), (Pamekasan: LP2SI),3.

${ }^{30}$ Hasil wawancara dengan beberapa tokoh di desa Bujur Tengah, kecamatan Batumarmar, kabupaten Pamekasan, seperti Ust. Abdul Mukti, Ustadz Abdul Kasan

${ }^{31}$ Yang dimaksud dengan abangan adalah sekelompak orang yang tidak pernah menjadi santri dan tidak memiliki pola pikir, pola sikap, dan pola laku sebagaimana kiai dan atau santri.

${ }^{32}$ Hasil diskusi dan cangkruan dengan beberapa pengelola STIU al-Mujtama' Pamekasan, seperti Zainal Abidin, S.PdI; Lasan Masduqi, S.HI., Nama yang disebut terakhir ini adalah sarjana Syariah yang pernah meneliti dan menuliskan tentang potensi zakat produktif di Kabupaten Pamekasan. Data diambil pada tanggal 3 bulan Rajab 2015. Jam 15.15 hingga menjelang Maghrib. 
mengembangkannya dalam bentuk dana untuk kegiatan yang lebih kreatif dan produktif.

\section{Prioritas Distribusi Zakat}

Salah satu tujuan pensyariatan zakat adalah mengurangi jurang pemisah antara orang kaya dengan fakir-miskin, dengan cara mencukupi kebutuhan orang-orang fakir-miskin dalam memenuhi hajatnya. Oleh sebab itu, sedekah atau zakat diberikan pada fakir-miskin agar supaya mereka bisa keluar dari jeratan kefakirannya sehingga mereka tidak selalu bergantung kepada orang lain. ${ }^{33}$ Lebih lanjut, Hasbi mengemukakan sebuah hadis Nabi yang diriwayatkan oleh Imam Ahmad, Muslim, Abū Daud dan al-Nasā' $\bar{i}$ yang bermaksud:

"Aku telah membebani satu hamalah (beban orang lain), maka aku datang kepada Rasulullah, aku memohon pertolongannya, karena itu beliau berkata kepadaku, "Tinggallah kamu di sini", hingga datang padaku sedekah, kemudian sedekah itu akan kuperintahkan agar diberikan kepadamu, kemudian Beliau bersabda, "Hai Qubaișah, tidak halal bagi seseorang meinta zakat melainkan karena tiga sebab; pertama, ia menanggung hutang yang diperbuat dan hendaklah ia mengambil sesuai keperluannya saja. Kedua, orang yang musnah hartanya, ia boleh meminta sekadar perlu benar bagi hidupnya. Ketiga, orang yang jatuh fakir dan harus diakui kefakirannya oleh tida orang yang terpandang dari kaumnya. Selain dari tiga orang itu, wahai Qubaișah: tidak ada yang boleh meminta zakat untuknya, haram ia memakannya ". ${ }^{34}$

Senada dengan pemahaman hadis di atas, apa yang dikemukakan oleh Shaikh al-Nawāwì sebagaimana dikutip oleh T.M. Hasbi al-Shiddiqiy yang menyatakan, "Sekiranya seorang sanggup berusaha yang berpadanan dengan kemampuannya, tetapi ia sibuk mencari ilmu agama, dalam arti jika mempergunakan waktu berusaha, ia tidak mencari ilmunya itu, maka orang yang demikian itu bolehlah menerima zakat, karena mencari ilmu itu fardu kifayah. Adapun orang yang tidak mungkin memperoleh ilmu, tidak halal mengambil zakat, jika ia sanggup berusaha, walaupun ia bermukim di sekolah." Selanjutanya, masih pendapat al-Nawāwi yang dikutip alShiddiqiy, "Orang yang terus-menerus mengerjakan ibadah sunnah, atau menggunakan seluruh waktunya untuk ibadah, maka tidak halal baginya

\footnotetext{
${ }^{33}$ T.M. Hasbi al-Shiddieqy, Op.Cit. 168.

${ }^{34}$ Ibid. 169.
} 
mengambil zakat, karena maslahat ibadahnya hanya untuk dirinya sendiri saja, berbeda dengan orang yang mencari ilmu". ${ }^{35}$

Berdasarkan paparan dan hadis Nabi di atas, maka skala prioritas harus menjadi perhatian bagi para muzakki yang masih mendistribusikan zakatnya secara tradisional alias berdasarkan kebiasaan dan tidak organisasianal atau kelembagaan, sehingga untuk mengevaluasi target, tujuan dan sasaran pendistribusian zakat sangat kesulitan, bahkan bisa dikatakan tidak tepat sasaran, seperti kasus yang banyak terjadi di pulau Madura, dimana kebanyakan zakat diberikan kepada para guru ngaji atau kiai yang sudah kaya (haji atau sudah daftar haji), punya usaha, dan bahkan bermobil. ${ }^{36}$ Oleh sebab itu, tidak heran apabila janda tua, yatim-miskin, fakir miskin, abang becak, buruh cuci rumah tangga dan lainnya hanya mendapatkan sebagian kecil dari percikan dana zakat yang semestinya mereka terima agar mereka bisa merubah nasibnya di masa yang akan datang.

\section{Pengelolaan Zakat Produktif}

Kiai Sahal menawarkan solusi agar zakat diarahkan pada penyelesaian kemiskinan secara struktural. Dengan kalimat yang berbeda Dawam Rahardjo juga mengatakan bahwa zakat adalah bagian dari pendapatan dan kekayaan masyarakat yang berkecukupan yang menjadi hak dan karena itu harus diberikan kepada yang berhak, terutama untuk memberantas kemiskinan dan penindasan. ${ }^{37}$ Maka untuk mewujudkan tawaran di atas, zakat harus dikelola secara kreatif dan produktif.

Pada umumnya, para intelektual muslim di Indonesia mendefinisikan Zakat produktif adalah dana zakat yang diberikan kepada seseorang atau sekelompok masyarakat untuk digunakan sebagai modal kerja agar dapat meningkatkan pendapatan bagi para penerima zakat. ${ }^{38}$

Pengelolaan zakat produktif diharapkan dapat berpengaruh positif bagi para penerima zakat, baik secara ekonomi, pendidikan maupun aspek

\footnotetext{
${ }^{35}$ Ibid. 208-209.

${ }^{36}$ Padahal kasus ini sangat jelas bertentangan dengan hadis Nabi yang berbunyi: yang artinya, sedekah itu tidak halal bagi orang kaya yang mempunyai tenaga untuk berusaha (H.R. Ahmad, al-Nasā'̄i dan al-Turmudhì), Bandingkan juga dengan Imam al-Shaukani, Nail al-Autār, Juz 4, halaman 224.

${ }^{37}$ Khusnul Huda (2012), Fikih Pengelolaan Zakat Produktif Sebagai Upaya Pengembangan Sumber Daya Mustahik (Studi Kasus di Badan Pelaksana Urusan Zakat Muhammadiyah (BAPELURZAM) Pimpinan Cabang Muhammadiyah Weleri Kendal, sinopsis Tesis (Semarang: Program Magister Institut Agama Islam Negeri (IAIN) Walisongo Semarang), 13.

${ }^{38}$ Ibid.7-8.
} 
sosialnya. Dari aspek ekonomi, para penerima zakat diharapkan mampu berdikari, sehingga dalam waktu yang tidak begitu lama, mereka dapat menjelma dari mustahiq menjadi muzakki; selanjutnya, mereka akan selalu berbenah diri, untuk meningkatkan kualitas hidup, dan juga pendidikannya, dan jika demikian, maka para mantan mustahiq ini akan dapat hidup penuh percaya diri dan dapat hidup sejajar dengan masyarakat lain, karena ia sudah merasa sama dalam berbagai aspek kehidupannya dengan orang lain.

Berdasarkan pembahasan di atas, maka dapat ditarik beberapa kesimpulan bahwa zakat yang dikelola dengan baik, kreatif dan produktif dapat menanggulangi kemiskinan dan menringankan beban APBN dan atau APBD. Selain itu, zakat produktif juga dapat meningkatkan kualitas hidup, kualitas ekonomi, pendidikan dan strata sosial apabila ia dikelola dan didistribusikan dengan baik dan tepat sasaran. Oleh sebab itu, tidak berlebihan rasanya, jika penulis menyimpulkan bahwa pendayagunaan zakat produktif dapat membangkitkan dan mengembangkan serta mewujudkan raksasa peradaban yang akan menggantikan peradaban Barat yang sudah diramalkan akan segera runtuh dan akan diganti oleh sebuah peradaban yang akan muncul dari Asia tenggara itu, seperti yang dituliskan seorang berkebangsaan Amerika yang bernama Samuel P. Huntington dalam bukunya The Clash of Civilizations, yang dipublikasikan oleh Simon \& Schuster, pada tahun 1996.

\section{Epilog}

Zakat merupakan salah satu rukun Islam yang berkaitan langsung dengan masalah kekayaan dan kesejahteraan umat Islam. Salah satu tujuan utama zakat adalah pemerataan kekayaan dan kesejahteraan sehingga dapat mengurangi jurang pemisah antara kaum aghniyā' (kaya) dan kaum mustad'afín (lemah). Oleh sebab itu, pendistribusian zakat selalu dipreoritaskan pada kaum yang lebih lemah.

Sebagaimana pembahasansebelumnya, bahwa beberapa mustahik yang dinyatakan dalam surat al-Taubah ayat $60 \mathrm{itu}$, perlu dipertimbangan untuk selalu menerima zakat, seperti riqa $\bar{b}$ dengan alasan, saat ini sudah tidak ada lagi sistem perbudakan di berbagai belahan bumi ini; kedua,mu'allaf, disebabkan para mu'allafzaman modern ini bukanlah orang yang lemah dan agama Islam sudah dimenangkan dan dijayakan oleh Allah sebagaimana yang difatwakan oleh Umar bin Khattāb; ketiga, Ghārim, dalam kehidupan modern ini, hampir semua orang memiliki hutang, baik yang pegawai negeri sipil (PNS), pegawai swasta, petani, pedagang dan lainnya; keempat, sabilillāh, dimana zakat tidak boleh didistribusikan ke luar balad, sedang balad kita sedang aman dan tidak ada perang; dan kelima, 
Ibnu Sabīl, menurut pandangan ulamā', ibnu sabīl zamat modern ini susah didapat, karena teknologi komunikasi dan transportasi sudah memungkinkan untuk meminta bantuan dari kampung halamannya. Oleh sebab itu, pendistribusian zakat harus diprerioritaskan pada fakir, miskin dan amil yang ditunjuk pemerintah.

Zakat yang dikelola dengan baik, kreatif dan produktif dapat menanggulangi kemiskinan, dan kebodohan yang merupakan penyebab dari berbagai penyakit sosial. Kemiskinan dan kebodohan merupakan penyebab terjadinya kemunduran suatu peradaban manusia. Oleh sebab itu, Islam datang dan memberikan solusi terbaik untuk umat Islam. Selain itu, zakat juga dapat membangun bangsa dan Negara dengan jalan meringankan beban Anggaran Pendapatan Belanja Negara (APBN)dan atau Anggaran Pendapatan Belanja Daerah (APBD). Zakat produktif juga dapat meningkatkan kualitas hidup, kualitas ekonomi, pendidikan, dan strata sosial apabila ia dikelola dan didistribusikan dengan baik dan tepat sasaran, kemudian ia dapat membangkitkan spirit pembangunan peradaban Islam peradaban Islam yang rahmatan lil 'ālamin, dan kemudian terbangun negeri yang baldatun tayyibatun wa rabbun ghafür (Negara yang baik dan berkemajuan), amin.

\section{Daftar Pustaka}

Ali Atabik dan Muhdlor Zuhdi Ahmad, Kamus al-'Asri: Arab-Indonesia, Yogyakarta: Yayasan Ali Ma'sum, Pondok Pesantren Krapyak, 1999

Al-Basri al-Mawardi, al-Hāwì al-Kabìr fì fiqh madhāhib al-Imām al-Shāfi ‘ $\bar{i}$ Radiya Allāhu 'anhu, Cet. Ke-1, Vol. 3, Bairut, Lubnān: Dār alKutub al-Ilmiah,1994

Al-Shiddieqy Hasbi, Pedoman Zakat, Semarang: PT. Pustaka Rizki Putra, 2006

Tafsìr al-Qur'ān al-Majīd al-Nūr, juz 4. Jakarta: Cakrawala Publishing, 2011

Al-Sharbini al-Khatīb, Mughni al-Muhtạj ilā ma’rifati ma'ānì al-alfāz alMinhāj, Juz 1, Bairut: Dār al-Ma'rifah, 1998

Asrori A. Ma'ruf dan Imam Ghazali Said, Ahkām al-Fuqahā': Solusi Problematika Aktual Hukum Islam, Keputusan Muktamar, Munas dan Kombes Nahdlatul Ulama 926-1999, cet.2. Surabaya: LTN-NU JATIM-Diantama, 2005

Al-Shaukani, Nail al-Auțār, Juz 4, ttp, 1999

Abū Zakariyā, Yahya, Rauḍạ al-Tālibīn, Juz 2, Raudạ al-Tālibīn, Juz 2, Dār Alām al-Kutub, 2003 
Baltaji Muhammad, Ijtihad Umar bin Khattab Dalam Penetapan Syariat Islam, Selangor: Berlian Publication SDN. BHD, 2007

Huda, Khusnul, Fikih Pengelolaan Zakat Produktif Sebagai Upaya Pengembangan Sumber Daya Mustahik (Studi Kasus Di Badan Pelaksana Urusan Zakat Muhammadiyah (BAPELURZAM) Pimpinan Cabang Muhammadiyah Weleri Kendal, sinopsis Tesis Semarang: Program Magister Institut Agama Islam Negeri Walisongo Semarang, 2012

Lembaga Pengkajian dan Penerapan Syariat Islam (LP2SI), mengenal Gerbang Salam (Gerakan Pembangunan Masyarakat Islami), (Pamekasan: LP2SI, 2010

Rasjid Sulaiman, al-Fiqh al-Islami, Bandung: Sinar Baru Algensindo, 2004

Sabiq Al-Sayyid (ttb), Fiqh al-Sunnah, Edisi Khusus, Vol.1, Kairo: al-Fath lil a'lạm al-'Arabī, tth 